\title{
Virulence Characterization of Wheat Stripe Rust Fungus Puccinia striiformis f. sp. tritici in Ethiopia and Evaluation of Ethiopian Wheat Germplasm for Resistance to Races of the Pathogen from Ethiopia and the United States
}

\begin{abstract}
Anmin Wan, Department of Plant Pathology, Washington State University, Pullman 99164-6430; Kebede T. Muleta, Department of Crop and Soil Sciences, Washington State University, Pullman 99164-6420, and Ethiopian Institute of Agricultural Research (EIAR), Addis Ababa, Ethiopia; Habtemariam Zegeye and Bekele Hundie, EIAR, Kulumsa Agricultural Research Center, Assela, Ethiopia; Michael O. Pumphrey, Department of Crop and Soil Sciences, Washington State University; and Xianming Chen, United States Department of Agriculture-Agricultural Research Service Wheat Health, Genetics, and Quality Research Unit, and Department of Plant Pathology, Washington State University
\end{abstract}

\begin{abstract}
Stripe rust, caused by Puccinia striiformis f. sp. tritici, is one of the most important diseases of wheat in Ethiopia. In total, 97 isolates were recovered from stripe rust samples collected in Ethiopia in 2013 and 2014. These isolates were tested on a set of $18 \mathrm{Yr}$ single-gene differentials for characterization of races and 7 supplementary differentials for additional information of virulence. Of $18 P$. striiformis $\mathrm{f}$. sp. tritici races identified, the 5 most predominant races were PSTv-105 (21.7\%), PSTv-106 (17.5\%), PSTv-107 (11.3\%), PSTv-76 (10.3\%), and PSTv$41(6.2 \%)$. High frequencies $(>40 \%)$ were detected for virulence to resistance genes $Y r 1, Y r 2, Y r 6, Y r 7, Y r 8, Y r 9, Y r 17, Y r 25, Y r 27, Y r 28, Y r 31$, $Y r 43, Y r 44, Y r E x p 2$, and $Y r A$. Low frequencies $(<40 \%)$ were detected

for virulence to $\operatorname{Yr} 10, \operatorname{Yr} 24, \operatorname{Yr} 32, \operatorname{YrTr} 1$, Hybrid 46, and Vilmorin 23. None of the isolates were virulent to $\operatorname{Yr} 5, \mathrm{Yr} 15, \mathrm{YrSP}$, and YrTye. Among the six collection regions, Arsi Robe and Tiyo had the highest virulence diversities, followed by Bekoji, while Bale and Holeta had the lowest. Evaluation of 178 Ethiopian wheat cultivars and landraces with two of the Ethiopian races and three races from the United States indicated that the Ethiopian races were more virulent on the germplasm than the predominant races of the United States. Thirteen wheat cultivars or landraces that were resistant or moderately resistant to all five tested races should be useful for breeding wheat cultivars with resistance to stripe rust in both countries.
\end{abstract}

Wheat is the fourth most important staple food crop in Ethiopia. It is cultivated on a total area of 1.7 million ha with estimated annual production of 4.2 million metric tons (CSA 2014). Ethiopia is the second largest wheat producer in sub-Saharan Africa, and wheat is becoming a key strategic crop for improving food security in this country (FAOSTAT 2014; Negassa et al. 2013). Wheat production, however, is continuously hampered by pests and abiotic stresses, especially stripe rust.

Stripe rust, caused by Puccinia striiformis f. sp. tritici Erikss., is an economically important disease of wheat in Ethiopia (Atilaw et al. 2014; Dereje and Chemeda 2006; Mengistu et al. 1991; Wellings 2011). The disease is a major threat to wheat production resulting in substantial yield and quality losses (Bekele et al. 2002; Dereje and Chemeda 2006; Mulugeta 1986). Grain yield losses of 71 to

Corresponding author: X. M. Chen; E-mail: xianming@wsu.edu

A. Wan and K. T. Muleta made equal contributions to the work.

PPNS Number 0706, Department of Plant Pathology, College of Agricultural, Human, and Natural Resource Sciences, Agricultural Research Center, project number WNP00663 (projects 13C-3061-5665), Washington State University, Pullman.

Mention of trade names or commercial products in this publication is solely for the purpose of providing specific information and does not imply recommendation or endorsement by the U.S. Department of Agriculture. USDA is an equal opportunity provider and employer.

*The $\boldsymbol{e}$-Xtra logo stands for "electronic extra" and indicates that two supplementary tables are published online.

Accepted for publication 24 July 2016.

This article is in the public domain and not copyrightable. It may be freely reprinted with customary crediting of the source. The American Phytopathological Society, 2017.
96,20 to 28 , and $12 \%$ on susceptible, moderately resistant, and resistant varieties, respectively, have been recorded (Dereje and Chemeda 2006). In the past two decades, frequent epidemics of stripe rust have been a major challenge to wheat production in the country. The breakdown of resistance conferred by $\operatorname{Yr} 9$ due to the emergence of virulent races of $P$. striiformis f. sp. tritici in the late $1980 \mathrm{~s}$ resulted in major epidemics of stripe rust that challenged wheat production in Ethiopia and the rest of the world (Chen et al. 2014; Wellings 2011; Zewde et al. 1989). In 2010, Ethiopia experienced a devastating stripe rust epidemic that affected more than 600,000 ha of wheat and led to an expenditure of more than \$US 3.2 million on fungicides, while significant, widespread losses were still realized (Abeyo et al. 2014; http://wheatrust.org/). Ethiopia and the neighboring countries in the East African highlands have long been considered among the countries at the highest risk of stripe rust (Wellings 2011).

Growing resistant cultivars is a mostly preferred approach for control of stripe rust because it is an economic, effective, easy-touse, and environmentally friendly strategy (Chen 2005, 2013). However, resistant cultivars can become susceptible due to changes in the pathogen population dynamics. Virulence characterization of the pathogen population on a regular basis is required to devise effective disease management by deploying effective resistance genes. There were virulence surveys for wheat rust pathogens on a regular basis between the early 1970s and late 1980s (Aklilu 1995). There was no such a study until recently, when Dawit et al. (2009) characterized virulence patterns of $P$. striiformis f. sp. tritici samples collected in 2005 . Since then, the $P$. striiformis f. sp. tritici virulence survey has been stopped again. However, epidemics of wheat stripe rust have become more frequent and widespread at high elevations in recent years (Wubishet et al. 2015). Only a few stripe rust samples have been sent recently to the Global Rust Reference Center in Denmark to determine their virulence (http://wheatrust.org/), which may not represent the whole P. striiformis f. sp. tritici population in Ethiopia. More detailed studies using stripe rust samples collected from every major wheat-growing region 
are needed to have a better understanding of the $P$. striiformis $\mathrm{f}$. sp. tritici population.

In 2013 and 2014, stripe rust samples were collected from six major wheat-growing regions in Ethiopia. The objectives of this study were to identify and determine the frequencies and distributions of $P$. striiformis $\mathrm{f}$. sp. tritici races, determine frequencies and distributions of individual virulence from these samples, and determine the effects of $P$. striiformis $\mathrm{f}$. sp. tritici races on Ethiopian wheat landraces and cultivars. The information on races and virulence and their impacts on wheat cultivars are useful in breeding wheat cultivars with effective and durable resistance to stripe rust, and the study lays a basis for monitoring virulence changes in the future.

\section{Materials and Methods}

Sample collection, isolate recovery, and spore production. During the 2013 and 2014 cropping seasons, common wheat, durum wheat, and triticale leaves with $P$. striiformis uredinia were collected from disease nurseries, breeding plots, and growers' fields in six major wheat-growing regions in Ethiopia: Arsi Robe, Bale, Bekoji, Holeta, South Wollo, and Tiyo (Fig. 1). With different cropping systems, elevations, and climates, these regions cover the major wheat production regions in the southeast (Arsi Robe and Bale), southcentral (Tiyo and Bekoji), central highlands (Holeta), and north (South Wollo) of Ethiopia.

To recover urediniospores, a piece of leaf (approximately $3 \mathrm{~cm}$ in length) with uredinia from each sample was incubated on moist blotting paper in a petri dish kept at $4^{\circ} \mathrm{C}$ overnight. Fresh urediniospores from the leaf sample were used to inoculate seedlings of susceptible wheat 'Nugaines' with a fine brush. Inoculated plants were kept in a dew chamber at $10^{\circ} \mathrm{C}$ for $24 \mathrm{~h}$ without light and then transferred to a growth chamber at a diurnal temperature cycle, gradually changing from $4^{\circ} \mathrm{C}$ at 2:00 A.M. to $20^{\circ} \mathrm{C}$ at 2:00 P.M., with $8 \mathrm{~h}$ of darkness and $16 \mathrm{~h}$ of light (Chen and Line 1992; Chen et al. 2002, 2010; Wan and Chen 2014). To prevent cross contamination, plants inoculated with different isolates were separated in plastic booths. Fresh urediniospores or those kept in a desiccator at $4{ }^{\circ} \mathrm{C}$ were used for virulence tests.
Determination of virulence and identification of races. The virulence and avirulence of each isolate were determined by testing on the standard set of $18 \mathrm{Yr}$ single-gene differentials and the set of 7 supplemental differentials, as described by Wan and Chen (2014). Seedlings at the two-leaf stage were inoculated with urediniospores mixed with talc at a ratio of 1:20. Inoculated plants were kept in a dew chamber for $24 \mathrm{~h}$ at $10^{\circ} \mathrm{C}$, then moved to a growth chamber with the same temperature and light conditions as described above. Infection types (IT) were recorded 18 to 20 days after inoculation using a 0 -to-9 scale (Chen et al. 2002; Line and Qayoum 1992). IT values of 0 to 6 were considered avirulent (A) and 7 to 9 virulent (V) (Wan and Chen 2014). If an initial sample produced virulence patterns different from previously identified races, subisolates were obtained from the differentials showing susceptible reactions different from a previously identified race with similar virulence/avirulence patterns. The subisolates were tested on the complete set of differentials to confirm the new virulence/avirulence patterns or identify different races in the original sample. If an isolate had a virulence/avirulence pattern different from previously identified races, a single-uredinium isolate was obtained and the purified isolate was tested again on the standard differential set to confirm the pattern. The PSTv series was used to name races based on the virulence/avirulence patterns on the standard set of $18 \mathrm{Yr}$ single-gene line differentials, together with octal codes derived from the patterns (Wan and Chen 2014; Wan et al. 2016). The virulence data of the isolates on the supplementary differentials were used to compare with previously reported virulence in Ethiopia and other countries.

Analyses of races and virulence. $P$. striiformis f. sp. tritici races, their frequencies and distribution, and frequencies of virulence to $\mathrm{Yr}$ genes or differential genotypes were analyzed. To estimate the virulence diversity in the geographic regions sampled in Ethiopia, Nei's diversity (Hs) (Nei 1973), Kosman index (Kw) (Kosman 1996), and Gleanson index of richness (G) (McVey et al. 2004) were analyzed using the Virulence Analysis Tool program (Herrmann et al. 2009).

Evaluation of Ethiopian bread wheat germplasm with $P$. striiformis f. sp. tritici races from Ethiopia and the United States. In total, 178 Ethiopian bread wheat accessions, including 65 cultivars and 113 landraces, were evaluated for seedling reactions to two

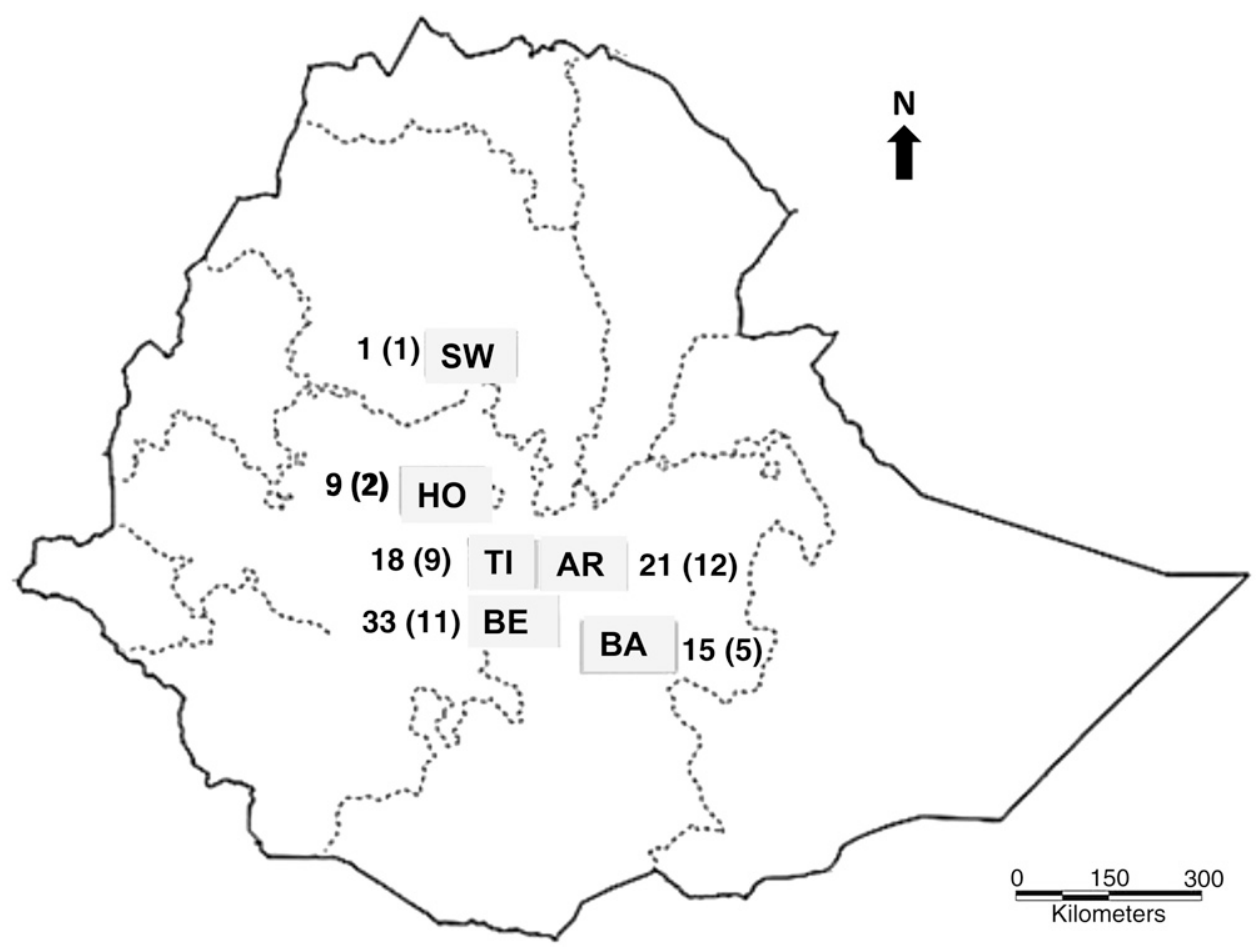

Fig. 1. Six regions of wheat stripe rust collection in Ethiopia in 2013 and 2014. Numbers outside of the parentheses indicate the size of samples collected from each region and those in the parentheses indicate the number of races identified. $\mathrm{AR}=$ Arsi Robe, $\mathrm{BA}=$ Bale, $\mathrm{BE}=$ Bekoji, $\mathrm{HO}=$ Holeta, $\mathrm{SW}=$ South Wollo, and $\mathrm{TI}=\mathrm{Tiyo}$ regions . 
P. striiformis f. sp. tritici races (PSTv-41 and PSTv-106) identified in this study and three previously characterized races (PSTV-14, PSTv-37, and PSTv-40) from the United States (Wan and Chen 2014). The accessions were obtained from the Kulumsa Experimental Station of Ethiopian Institute of Agricultural Research. The five $P$. striiformis f. sp. tritici races used for the resistance screening were selected based on their wide virulence spectra on the differential lines and distribution in Ethiopia or the United States. PSTv-106 was the most widely distributed race in Ethiopia determined in this study. PSTV-41 has the highest number of virulences identified in the United States (Wan and Chen 2014). PSTv-37 is a predominant and widely distributed race in the United States. PSTV-14 and PSTv-40, representing different race groups, were predominantly in the Pacific Northwest of the United States (Wan and Chen 2014). The conditions and procedures for seedling tests were the same as described above for race identification.

\section{Results}

Races and their virulence, frequencies, and distributions. From a total of 103 stripe rust samples collected in 2013 and 2014, 97 $P$. striiformis f. sp. tritici isolates were obtained, of which 86 were from common wheat, 10 from durum wheat, and 1 from triticale. The virulence/avirulence data on the $18 \mathrm{Yr}$ single-gene differentials and 7 supplementary differentials are given in Supplementary Table $\mathrm{S} 1$. From the 97 isolates, 18 races were identified. The virulence/ avirulence formulae on the $18 \mathrm{Yr}$ genes, together with frequencies and distributions, are presented in Table 1 . The number of virulences on the $18 \mathrm{Yr}$ single-gene differentials ranged from 7 to 13 . The races with the highest number of virulences were PSTv-41 ( $Y r 6, Y r 7, Y r 8, Y r 9$, Yr10, Yr17, Yr24, Yr27, Yr32, Yr43, Yr44, YrTr1, and YrExp2) and PSTv-110 (Yrl, Yr6, Yr7, Yr8, Yr9, Yr10, Yr17, Yr24, Yr27, Yr32, $Y r 43, Y r 44$, and $Y r E x p 2)$ with 13 virulences. PSTv-139 (Yr6, Yr7, $Y r 8$, $\mathrm{Yr}$ 9, $\mathrm{Yr}$ 27, $\mathrm{Yr}$ 44, and $\mathrm{YrExp2}$ ) had the lowest number of virulences. The frequencies of the 18 races in the country ranged from 1.0 (only one isolate) to $21.7 \%$. The top five predominant races were PSTv-105 (21.7\%), PSTv-106 (17.5\%), PSTv-107 (11.3\%), PSTv-76 (10.3\%), and PSTv-41 (6.2\%). The frequencies of the remaining 13 races were less than $5.5 \%$, with 5 races detected only once.
The distributions of races in the regions are presented in Table 1. In general, races with higher frequencies tended to occur in more regions. The top five most frequent races were detected in at least three regions. Race PSTv-106, with a frequency of $17.5 \%$, was detected in five regions, and races PSTV-105 (21. 7\%), PST-107 (11.3\%), and PSTV-76 (10.3\%) were detected in four regions, indicating that these predominant races are adapted to the wheat cultivars and environments in these regions. For each region, the number of isolates, number of races, mean number of virulences for each race, and the number of isolates for each race are given in Table 2. Except for only one isolate from South Wollo, the other five regions had 9 to 33 isolates, which allowed us to compare the pathogen populations among these regions. The highest number of races were identified in Arsi Robe (12 races), followed by Bekoji (11 races), Tiyo ( 9 races), and Bale (5 races). Two races were identified in Holeta, and only one race was identified from a triticale sample collected from South Wollo (Fig. 1; Table 2).

Frequencies and distribution of virulence. Among the $18 \mathrm{Yr}$ single-gene lines used to differentiate $P$. striiformis f. sp. tritici races, high frequencies ( $>40 \%$ ) of virulence were detected to $\mathrm{Yr} 6, \mathrm{Yr} 7, \mathrm{Yr}$, Yr27, and $\operatorname{YrExp2}(100 \%) ; \operatorname{Yr} 43$ (91.8\%); Yrl7 (88.7\%); Yrl (74.2\%); $Y r 44$ (66.0\%); and $Y r 8$ (55.7\%) (Fig. 2). Low frequencies $(<40 \%)$ were detected for virulence to $\operatorname{Yr} 10$ (35.1\%), $\operatorname{Yr} 32$ (30.9\%), $\operatorname{Yr} 24(26.8 \%)$, and $\operatorname{YrTr} 1$ (10.3\%). No virulence were detected to $Y r 5, Y r 15, Y r S P$, and $Y r T y e$. Virulence to $Y r 1, Y r 6, Y r 7$, $Y r 9, Y r 17, Y r 27, Y r 43, Y r 44$, and $Y r E x p 2$ was detected in all five regions, with multiple isolates and virulences to $\operatorname{Yr} 6, \operatorname{Yr} 7, \operatorname{Yr} 8, \operatorname{Yr} 9$, Yr27, $Y r 44$, and $Y r E x p 2$ also detected in the only isolate from South Wollo (Table 1). Virulence to $\operatorname{Yr} 8, \operatorname{Yr} 10, \operatorname{Yr} 32$, and $\operatorname{YrTr} 1$ was detected in Arsi Robe, Bale, Bekoji, and Tiyo; and virulence to $Y r 24$ was only detected in Arsi Robe, Bekoji, and Tiyo. Arsi Robe, Bale, Bekoji, and Tiyo had all 14 identified virulences $(\operatorname{Yr} 1, \operatorname{Yr} 6, \operatorname{Yr} 7, \operatorname{Yr} 8$, Yr9, Yr10, Yr17, Yr24, Yr27, Yr32, Yr43, Yr44, YrTr1, and YrExp2) and Holeta had 9 (Yr1, Yr6, Yr7, Yr9, Yr17, Yr24, Yr27, Yr43, Yr44, and $\operatorname{YrExp} 2)$ of the 14 virulences.

The frequencies of virulence on the supplementary differentials were high, except on 'Hybrid 46' ( $\mathrm{r}$ 4b, $\mathrm{YrH} 46)$ and 'Vilmorin 23' (Yr4a, YrV23) (Fig. 2). The frequency of virulence to 'Kalyansona'

Table 1. Races and their octal codes, virulence formula, frequencies (Freq), and distribution of Puccinia striiformis f. sp. tritici detected in six locations in Ethiopia in 2013 and $2014^{\mathrm{a}}$

\begin{tabular}{|c|c|c|c|c|c|c|}
\hline PSTv race & Octal code & $\begin{array}{l}\text { Virulence/avirulence on the standard set } \\
\text { of } 18 \mathrm{Yr} \text { single-gene line differentials }\end{array}$ & $\mathbf{V G}^{\mathbf{b}}$ & $N^{\mathrm{c}}$ & Freq $(\%)$ & Distribution in regions $(N)^{d}$ \\
\hline PSTV-41 & 175766 & $6,7,8,9,10,17,24,27,32,43,44, \operatorname{Tr} 1, \operatorname{Exp} 2 / 1,5,15, \mathrm{SP}, \mathrm{Tye}$ & 1 & 6 & 6.2 & $\mathrm{AR}(3), \mathrm{BE}(1), \mathrm{TI}(2)$ \\
\hline PSTV-47 & 571266 & $1,6,7,8,9,17,27,43,44, \operatorname{Tr} 1, \operatorname{Exp} 2 / 5,10,15,24,32, \mathrm{SP}, \mathrm{Tye}$ & 2 & 2 & 2.1 & $\mathrm{BA}(2)$ \\
\hline PSTv-72 & 175762 & $6,7,8,9,10,17,24,27,32,43,44, \operatorname{Exp} 2 / 1,5,15, \mathrm{SP}, \operatorname{Tr} 1$, Tye & 1 & 4 & 4.1 & $\mathrm{AR}(1), \mathrm{BE}(1), \mathrm{TI}(2)$ \\
\hline PSTV-76 & 571262 & $1,6,7,8,9,17,27,43,44, \operatorname{Exp} 2 / 5,10,15,24,32, \mathrm{SP}, \operatorname{Tr} 1$, Tye & 2 & 10 & 10.3 & $\mathrm{AR}(1), \mathrm{BA}(4), \mathrm{BE}(3), \mathrm{TI}(2)$ \\
\hline PSTv-105 & 551242 & $1,6,7,9,17,27,43, \operatorname{Exp} 2 / 5,8,10,15,24,32,44, \mathrm{SP}, \operatorname{Tr} 1$, Tye & 2 & 21 & 21.7 & $\mathrm{AR}(2), \mathrm{BE}(8), \mathrm{HO}$ (7), TI (4) \\
\hline PSTv-106 & 551262 & $1,6,7,9,17,27,43,44$, Exp2/5,8,10,15,24,32,SP,Tr1,Tye & 2 & 17 & 17.5 & $\mathrm{AR}(2), \mathrm{BE}(10), \mathrm{HO}(2), \mathrm{BA}(1), \mathrm{TI}(2)$ \\
\hline PSTv-107 & 571242 & $1,6,7,8,9,17,27,43$, Exp2/5,10,15,24,32,44,SP,Tr1,Tye & 2 & 11 & 11.3 & $\mathrm{AR}(1), \mathrm{BA}(7), \mathrm{BE}(2), \mathrm{TI}(1)$ \\
\hline PSTV-108 & 555262 & $1,6,7,9,10,17,27,43,44, \operatorname{Exp} 2 / 5,8,15,24,32, \mathrm{SP}, \operatorname{Tr} 1$, Tye & 2 & 2 & 2.1 & AR (2) \\
\hline PSTv-109 & 174266 & $6,7,8,9,10,27,43,44, \operatorname{Tr} 1, \operatorname{Exp} 2 / 1,5,15,17,24,32, \mathrm{SP}, \mathrm{Tye}$ & 1 & 1 & 1.0 & $\mathrm{BE}(1)$ \\
\hline PSTv-110 & 575762 & $1,6,7,8,9,10,17,24,27,32,43,44, \operatorname{Exp} 2 / 5,15, \mathrm{SP}, \mathrm{Tr} 1$, Tye & 2 & 5 & 5.2 & $\mathrm{AR}(2), \mathrm{BA}(1), \mathrm{BE}(1), \mathrm{TI}(1)$ \\
\hline PSTv-111 & 574762 & $1,6,7,8,9,10,24,27,32,43,44, \operatorname{Exp} 2 / 5,15,17, \mathrm{SP}, \operatorname{Tr} 1$, Tye & 1 & 1 & 1.0 & $\mathrm{BE}(1)$ \\
\hline PSTv-112 & 174762 & $6,7,8,9,10,24,27,32,43,44, \operatorname{Exp} 2 / 1,5,15,17, \mathrm{SP}, \operatorname{Tr} 1, \mathrm{Tye}$ & 1 & 4 & 4.1 & AR (3), TI (1) \\
\hline PSTv-113 & 555722 & $1,6,7,9,10,17,24,27,32,44, \operatorname{Exp} 2 / 5,8,15,43, \mathrm{SP}, \operatorname{Tr} 1, \mathrm{Tye}$ & 2 & 2 & 2.1 & AR (2) \\
\hline PSTv-114 & 154722 & $6,7,9,10,24,27,32,44$, Exp2/1,5,8,15,17,43,SP,Tr1,Tye & 2 & 1 & 1.0 & $\mathrm{BE}(1)$ \\
\hline PSTv-115 & 174722 & $6,7,8,9,10,24,27,32,44, \operatorname{Exp} 2 / 1,5,15,17,43, \mathrm{SP}, \operatorname{Tr} 1$, Tye & 1 & 4 & 4.1 & AR (1), TI (3) \\
\hline PSTv-116 & 175722 & $6,7,8,9,10,17,24,27,32,44, \operatorname{Exp} 2 / 1,5,15,43, \mathrm{SP}, \operatorname{Tr} 1$, Tye & 1 & 4 & 4.1 & $\mathrm{BE}(4)$ \\
\hline PSTV-117 & 571246 & $1,6,7,8,9,17,27,43, \operatorname{Tr} 1, \operatorname{Exp} 2 / 5,10,15,24,32,44, \mathrm{SP}$, Tye & 2 & 1 & 1.0 & $\mathrm{AR}(1)$ \\
\hline PSTv-139 & 170222 & $6,7,8,9,27,44, \operatorname{Exp} 2 / 1,5,10,15,17,24,32,43, \mathrm{SP}, \operatorname{Tr} 1$, Tye & 1 & 1 & 1.0 & SW (1) \\
\hline
\end{tabular}

a Race names, codes, and virulence formulae follow the descriptions by Wan and Chen (2014) and Wan et al. (2016). The following $18 \mathrm{Yr}$ single-gene lines were used to differentiate $P$. striiformis f. sp. tritici races: $1=$ AvSYr1NIL (Yr1), $5=$ AvSYr5NIL (Yr5), $6=$ AvSYr6NIL $(Y r 6), 7=$ AvSYr7NIL $(Y r 7), 8=$ AvSYr8NIL $(Y r 8), 9=$ AvSYr9NIL $(Y r 9), 10=$ AvSYr10NIL $(Y r 10), 15=$ AvSYr15NIL (Yr15), $17=$ AvSYr17NIL (Yr17), 24 = AvSYr24NIL (Yr24), $27=$ AvSYr27NIL (Yr27), $32=$ AvSYr32NIL (Yr32), $43=$ AvS/IDO377s (F3-41-1) $(Y r 43), 44=$ AvS/Zak (1-1-35-line1) $(Y r 44)$, SP = AvSYrSPNIL $(Y r S P)$, Tr1 = AvSYrTres1NIL (YrTr1), Exp2 = AvS/Exp 1/1-1 Line 74 (YrExp2), and Tye = Tyee (YrTye)

${ }^{\mathrm{b}}$ Virulence group.

${ }^{\mathrm{c}}$ Number of isolates.

${ }^{\mathrm{d}} \mathrm{AR}=$ Arsi Robe, $\mathrm{BA}=$ Bale, $\mathrm{BE}=$ Bekoji, $\mathrm{HO}=$ Holeta, $\mathrm{SW}=$ South Wollo, and $\mathrm{TI}=$ Tiyo for regions. 
(Yr2) was 100\%, 'AvSYr31NIL' (Yr31) was 99.0\%, 'Hugenoot' (Yr25) was 97.9\%, 'AvSYrANIL' ( $Y r A$, now known as $Y r 73$ and Yr74) was $82.5 \%$, and 'AvSYr28NIL' ( $Y r 28)$ was $75.3 \%$. The frequencies of virulence to Vilmorin 23 (29.9\%) and Hybrid 46 (5.2\%) were relatively low. Hybrid 46 was only susceptible to 3 (PSTv-76, PSTv-105, and PSTv-111) of the 18 races.

Diversity and genetic distance. Arsi Robe had the highest numbers of races $(n=12)$ and mean number of virulences $(n=10.6)$, whereas Holeta had the lowest number of races $(n=2)$ and virulences $(n=8.2)$ (Table 2). Based on the Hs, regions Arsi Robe and Tiyo had the highest diversity value (0.2), region Holeta had the lowest (0.02), and regions Bale and Bekoji were in between. Based on the $K w$, region Tiyo has the highest diversity (0.33), followed by Arsi Robe
(0.30), Bekoji (0.21), and Bale (0.09), with Holeta being the lowest. Similarly, the G showed Arsi Robe to have the richest of diversity (3.61), followed by Tiyo (2.77) and Bekoji (2.57), with Holeta again the lowest (0.46). Based on both Nei's and Kosman's KGst distance values, the populations of Arsi Robe and Holeta were more differentiated, whereas the populations of Arsi Robe and Tiyo were more closely related to each other than to any other regions (Table 3), indicating more urediniospore movement between Arsi Robe and Tiyo.

Reactions of Ethiopian wheat germplasm to $P$. striiformis $\mathbf{f}$. sp. tritici races from Ethiopia and the United States. The IT data of 178 Ethiopian wheat cultivars and landraces tested with two P. striiformis f. sp. tritici races from Ethiopia (PSTv-41 and PSTv-106) and three races from the United States (PSTv-14, PSTv-37, and PSTv-40)

Table 2. Number of isolates $(N)$, Nei's diversity $(\mathrm{Hs})$, Kosman index $(K w)$, Gleanson index of richness $(\mathrm{G})$, and identified races of Puccinia striiformis f. sp. tritici in Arsi Robe, Bale, Bekoji, Holeta, Tiyo, and South Wollo in Ethiopia in 2013 and 2014

\begin{tabular}{|c|c|c|c|c|c|c|c|}
\hline Location & $N$ & Races $^{\mathbf{a}}$ & Vir ${ }^{\mathbf{b}}$ & Hs & $K w$ & $\mathbf{G}$ & P. striiformis f. sp. tritici races $(N)^{\mathbf{c}}$ \\
\hline Arsi Robe & 21 & 12 & 10.6 & 0.20 & 0.30 & 3.61 & $\begin{array}{l}\text { PSTv-41(3), PSTv-72(1), PSTv-76(1), PSTv-105(2), PSTv-106(2), PSTv-107(1), } \\
\text { PSTv-108(2), PSTv-110(2), PSTv-112(3), PSTv-113(2), PSTv-115(1), } \\
\text { PSTv-117(1) }\end{array}$ \\
\hline Bale & 15 & 5 & 9.7 & 0.06 & 0.09 & 1.48 & PSTv-47(2), PSTv-76(4), PSTv-106(1), PSTv-107(7), PSTv-110(1) \\
\hline Bekoji & 33 & 11 & 9.6 & 0.15 & 0.21 & 2.57 & $\begin{array}{l}\text { PSTv-41(1), PSTv-72(1), PSTv-76(3), PSTv-105(8), PSTv-106(10), PSTv-107(2), } \\
\text { PSTv-109(1), PSTv-110(1), PSTv-111(1), PSTv-114(1), PSTv-116(4) }\end{array}$ \\
\hline Holeta & 9 & 2 & 8.2 & 0.02 & 0.03 & 0.46 & PSTv-105(7), PSTv-106(2) \\
\hline Tiyo & 18 & 9 & 10.1 & 0.20 & 0.33 & 2.77 & $\begin{array}{l}\text { PSTv-41(2), PSTv-72(2), PSTv-76(2), PSTv-105(4), PSTv-106(2), PSTv-107(1), } \\
\text { PSTv-110(1), PSTv-112(1), PSTv-115(3), }\end{array}$ \\
\hline South Wollo & 1 & 1 & NA & NA & NA & NA & PSTv-139(1) \\
\hline Total & 97 & 18 & 9.8 & 0.17 & 0.25 & 3.50 & $\begin{array}{l}\text { PSTv-41(6), PSTv-47(2), PSTv-72(4), PSTv-76(10), PSTv-105(21), PSTv-106(17), } \\
\text { PSTv-107(11), PSTv-108(2), PSTv-109(1), PSTv-110(5), PSTv-111(1), } \\
\text { PSTv-112(4), PSTv-113(2), PSTv-114(1), PSTv-115(4), PSTv-116(4), } \\
\text { PSTv-117(1), PSTv-139(1) }\end{array}$ \\
\hline
\end{tabular}

\footnotetext{
a Number of races.

${ }^{\mathrm{b}}$ Mean number of virulence. NA = not applicable.

${ }^{\mathrm{c}}$ Races detected only in the region are highlighted in bold.
}

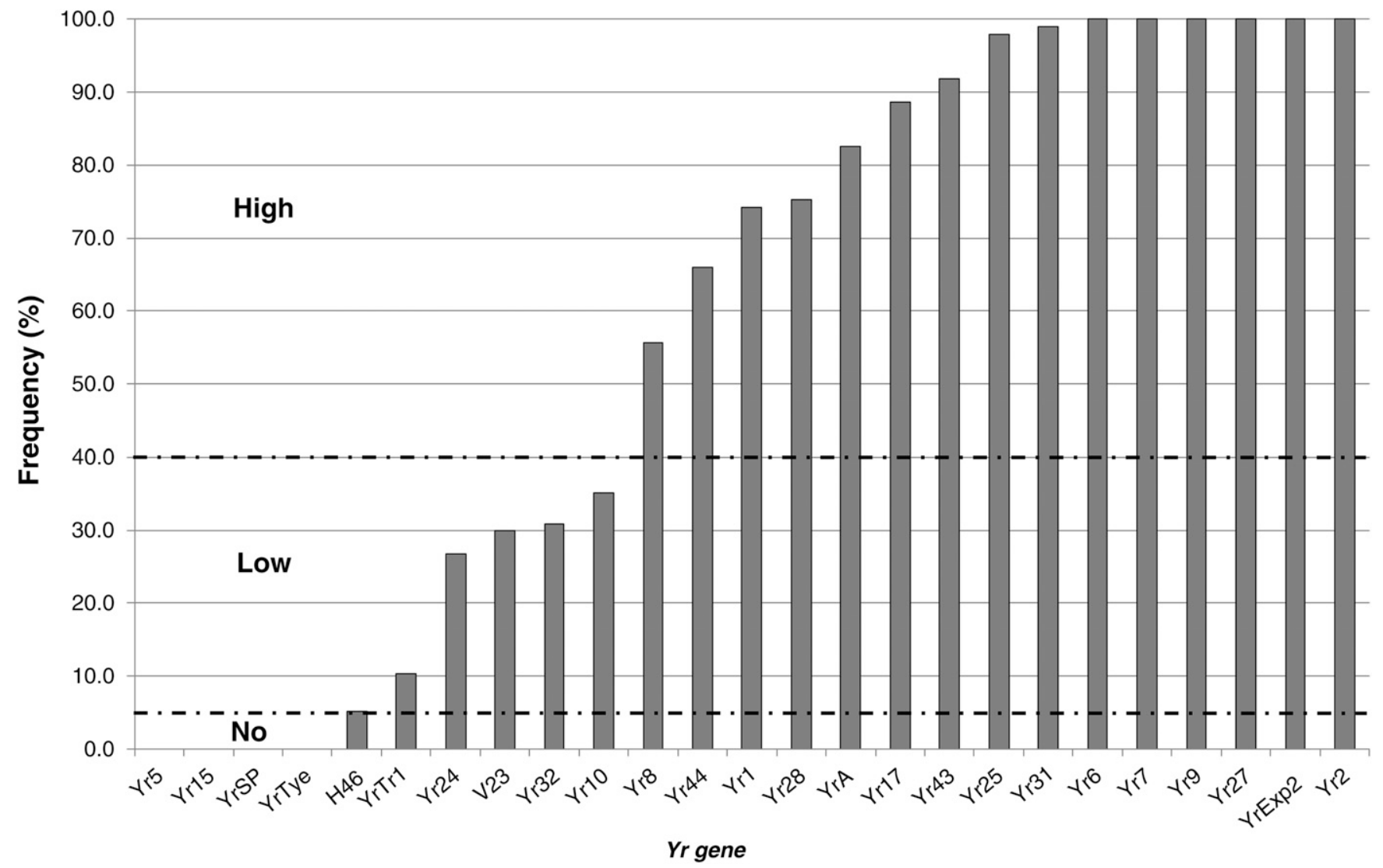

Fig. 2. Frequencies of virulence to Yr genes or cultivars identified from Puccinia striformis f. sp. tritici isolates collected from Ethiopia in 2013 and 2014. 
are presented in Supplementary Table S2, and the data are summarized in Table 4. Of the 65 cultivars, $14(21.5 \%)$ and $8(12.3 \%)$ were resistant (IT 0 to 3) to Ethiopian races PSTv-41 and PSTv-106, respectively, whereas more entries were resistant to the races from the United States, with $24(36.9 \%), 23(35.4 \%)$, and 21 (32.3\%) resistant to PSTv-14, PSTv-37, PSTv-40, respectively. Similarly, more cultivars were susceptible (IT 8 to 9) to the Ethiopian races (61.5\% to PSTV-41 and $43.1 \%$ to PSTV-106) than to the races from the United States (30.8\% to PSTv-14, $16.9 \%$ to PSTv-37, and 20.0\% to PSTv-40). Also, relatively high proportions of landraces were susceptible to Ethiopian races (73.2\% to PSTv-41 and $42.5 \%$ to PSTv-106) compared with races from the United States (9.7\% to PSTv-14, 19.6\% to PSTv-37, and $21.6 \%$ to PSTv-40). In general, relatively few landraces were resistant to Ethiopian races ( 8 to PSTv-41 and 36 to PSTv106) compared with those resistant to races from the United States (51 to PSTv-14, 33 to PSTv-37, and 37 to PSTv-40). When cultivars and landraces were combined, $122(69.3 \%)$ entries were susceptible to PSTv-41 and $76(42.7 \%)$ to PSTv-106, whereas 31 to 37 (17.4 to $21.0 \%$ ) entries were susceptible to the races of the United States. The results indicate that Ethiopian races are more adapted to the Ethiopian wheat germplasm than the predominant races from the United States.

Among the wheat cultivars, only three ('Huluka', 'Meraro', and 'Bolo') were resistant to both Ethiopian races PSTv-41 and PSTv106 and eight ('Alidoro', 'Tusie', 'Dinknesh', 'Menze', 'AMNA-4', 'Bounty', 'ETBW 5231', and 'Madda Walabu') were resistant to one and moderately resistant (IT 4 to 5) to another, or moderately resistant to both races. Four cultivars (Alidoro, Tusie, Menze, and Bolo) were resistant to all three races (PSTv-14, PSTv-37, and PSTv-40) from the United States; and four other cultivars (Dinknesh, AMNA-4, ETBW 5231, and Huluka) were resistant to some and moderately resistant to the others, or moderately resistant to all three races. For landraces, five accessions (232054A, 232055A, 232055B, 232013B, and 231655) were resistant to both Ethiopian races PSTv-41 and PSTv106 and two accessions (PI 384260 and 231961) were resistant to one and moderately resistant to the other, or moderately resistant to both races. When tested with the three races from the United States, 25 landraces were resistant to all three races and 13 were resistant to one or two and moderately resistant to the other race of the United States. When all five races were considered, eight cultivars (Alidoro, Tusie, Dinknesh, Menze, Bolo, AMNA-4, ETBW 5231, and Huluka) and five landraces (PI 384260, 232054A, 232055A, 232055B, and 232013B) were found to be resistant or moderately resistant to all of them, indicating that these cultivars and lines are useful in breeding programs in both countries.

\section{Discussion}

Ethiopia is one of the countries where stripe rust epidemics most frequently occur but there was no adequate information about races of the pathogen population (Badebo 2002; Badebo et al. 2008; Mulugeta 1986; Wellings 2011; Zewde et al. 1989). In the present study, we analyzed the virulence of stripe rust samples from the major wheat production regions in Ethiopia in 2013 and 2014 and identified 18 races using the recently established $\mathrm{Yr}$ singlegene differentials (Wan and Chen 2014; Wan et al. 2016). We determined the frequencies and distributions of the races and associated virulences in the various regions. To our knowledge, this is the

Table 3. Nei's and Kosman's KGst distances among the Puccinia striiformis f. sp. tritici populations in the Arsi Robe, Bale, Bekoji, Holeta, and Tiyo areas of Ethiopia ${ }^{\mathrm{a}}$

\begin{tabular}{lccccc}
\hline Locations & Arsi Robe & Bale & Bekoji & Holeta & Tiyo \\
\hline Arsi Robe & $\ldots$ & $0.091^{\mathrm{a}}$ & 0.028 & 0.140 & 0.004 \\
Bale & 0.078 & $\ldots$ & 0.045 & 0.062 & 0.078 \\
Bekoji & 0.028 & 0.030 & $\ldots$ & 0.065 & 0.021 \\
Holeta & 0.125 & 0.059 & 0.040 & $\ldots$ & 0.126 \\
Tiyo & 0.004 & 0.060 & 0.020 & 0.105 & $\ldots$ \\
\hline
\end{tabular}

a Nei's genetic distance (below diagonal) and Kosman's KGst genetic distance (above diagonal). first study on $P$. striiformis f. sp. tritici virulence in Ethiopia after the study of the 2005 collection by Dawit et al. (2009).

In the study of Dawit et al. (2009) with 107 isolates collected from Ethiopia in 2005, they identified virulence to $\operatorname{Yr} 6, \operatorname{Yr} 7, \operatorname{Yr} 8, \operatorname{Yr} 9$, Yr10, Yr24, Yr26, Yr27, and Yr32 but did not identified virulence to $\mathrm{Yrl}, \mathrm{Yr}$ 5, $\mathrm{Yr} 15$, and $\mathrm{YrSP}$ among the tested $\mathrm{Yr}$ single-gene lines in the 'Avocet $S$ ' background. With a comparable number of isolates collected from the similar regions in 2013 and 2014, we also identified virulence to $Y r 6, Y r 7, \operatorname{Yr} 8, \operatorname{Yr} 9, Y r 10, Y r 24, Y r 27$, and $Y r 32$. Similarly, we found that all of the isolates were avirulent to $\operatorname{Yr} 5, \mathrm{Yr} 15$, and $Y r S P$, indicating that these genes are still effective against the $P$. striiformis f. sp. tritici population in Ethiopia. However, we identified virulence to $\mathrm{Yrl}$ at a relatively high frequency (74\%). This is significant for understanding the pathogen evolution in Ethiopia and also in the world. The detection of the $\mathrm{Yrl}$ virulence is consistent with the previous identification of virulence in Kenya, neighboring Ethiopia, at a remarkably similar frequency (75\%) (SharmaPoudyal et al. 2013). It should be noted that $Y r 24$ and $Y r 26$ are considered to be the same gene ( $\mathrm{Li}$ et al. 2006; McIntosh et al. 2013). Because of this, Yr26 is not included in the set of $Y r$ single-gene differentials (Wan and Chen 2014; Wan et al. 2016) and was not used in the present study.

In addition to the $Y r$ single-gene lines in the Avocet $\mathrm{S}$ background that were used commonly by Dawit et al. (2009) and in the present study, they tested the 2005 isolates on 'Heines VII', Vilmorin 23, 'Nord Desprez', Hybrid 46, 'Heines Peko', 'Clement', 'Carstens V', 'Suwon 92' × 'Omar', and 'Stubes Dickkopf', which have been used as European or world differentials (Johnson et al. 1972). Most of the cultivars have more than one gene for all-stage resistance to stripe rust. They also included 'Anza'/'Avocet R' to represent $\mathrm{YrA}$ and

Table 4. Numbers of Ethiopian bread wheat accessions in categories of reactions to races of Puccinia striiformis $\mathrm{f}$. sp. tritici from Ethiopia and the United States

\begin{tabular}{|c|c|c|c|c|}
\hline \multirow[b]{2}{*}{ Race (country) } & \multirow{2}{*}{$\begin{array}{c}\text { Resistance } \\
\text { category }(\text { IT) }\end{array}$} & \multicolumn{3}{|c|}{ Number of accessions (\%) } \\
\hline & & Cultivars & Landraces & Total \\
\hline \multirow{5}{*}{$\begin{array}{l}\text { PSTv-41 } \\
\text { (Ethiopia) }\end{array}$} & $\mathrm{R}(0-3)$ & $14(21.5)$ & $8(7.1)$ & $22(12.5)$ \\
\hline & MR (4-5) & $5(7.7)$ & $3(2.7)$ & $8(4.5)$ \\
\hline & MS (6-7) & $5(7.7)$ & $19(17)$ & $24(13.6)$ \\
\hline & $S(8-9)$ & $40(61.5)$ & $82(73.2)$ & $122(69.3)$ \\
\hline & Total & $64(100)$ & $112(100)$ & $176(100)$ \\
\hline \multirow{5}{*}{$\begin{array}{l}\text { PSTv-106 } \\
\text { (Ethiopia) }\end{array}$} & $\mathrm{R}(0-3)$ & $8(12.3)$ & $36(31.9)$ & $44(24.7)$ \\
\hline & MR (4-5) & $7(10.8)$ & $8(7.1)$ & $15(8.4)$ \\
\hline & MS (6-7) & $22(33.8)$ & $21(18.6)$ & $43(24.2)$ \\
\hline & $S(8-9)$ & $28(43.1)$ & $48(42.5)$ & $76(42.7)$ \\
\hline & Total & $65(100)$ & $113(100)$ & $178(100)$ \\
\hline \multirow{5}{*}{$\begin{array}{l}\text { PSTv-14 } \\
\text { (United States) }\end{array}$} & $\mathrm{R}(0-3)$ & $24(36.9)$ & $51(45.1)$ & $75(42.1)$ \\
\hline & MR (4-5) & $8(12.3)$ & $17(15.0)$ & $25(14.0)$ \\
\hline & MS (6-7) & $13(20.0)$ & $34(30.1)$ & $47(26.4)$ \\
\hline & $S(8-9)$ & $20(30.8)$ & $11(9.7)$ & $31(17.4)$ \\
\hline & Total & $65(100)$ & $113(100)$ & $178(100)$ \\
\hline \multirow{5}{*}{$\begin{array}{l}\text { PSTv-37 } \\
\text { (United States) }\end{array}$} & $\mathrm{R}(0-3)$ & $23(35.4)$ & $33(29.5)$ & $56(31.6)$ \\
\hline & MR (4-5) & $14(21.5)$ & $20(17.9)$ & $34(19.2)$ \\
\hline & $\operatorname{MS}(6-7)$ & $17(26.2)$ & $37(33.0)$ & $54(30.5)$ \\
\hline & $S(8-9)$ & $11(16.9)$ & $22(19.6)$ & $33(18.6)$ \\
\hline & Total & $65(100)$ & $112(100)$ & $177(100)$ \\
\hline \multirow{5}{*}{$\begin{array}{l}\text { PSTv-40 } \\
\text { (United States) }\end{array}$} & $\mathrm{R}(0-3)$ & $21(32.3)$ & 37 (33.3) & $58(33.0)$ \\
\hline & MR (4-5) & $13(20.0)$ & $18(16.2)$ & $31(17.6)$ \\
\hline & MS (6-7) & $18(27.7)$ & $32(28.8)$ & $50(28.4)$ \\
\hline & $S(8-9)$ & $13(20.0)$ & 24 (21.6) & 37 (21.0) \\
\hline & Total & $65(100)$ & $111(100)$ & $176(100)$ \\
\hline
\end{tabular}

${ }^{\mathrm{a}}$ IT $=$ infection type, based on the 0-to- 9 scale as described by Line and Qayoum (1992), where $\mathrm{R}=$ resistant, $\mathrm{MR}=$ moderately resistant, $\mathrm{MS}=$ moderately susceptible, and $\mathrm{S}=$ susceptible. 
'Rendezvous' to represent $\mathrm{Yr} 17$. They detected virulence to all of these wheat genotypes. In the present study, we included Kalyansona $(Y r 2)$, Vilmorin 23 (Yr3, YrV23), Hybrid 46 (Yr4, YrH46), Hugenoot (Yr25), AvSYr28NIL (Yr28), AvSYr31NIL (Yr31), and AvSYrANIL (YrA) as supplementary differentials (Wan and Chen 2014; Wan et al. 2016). We also detected virulence to these genotypes. The detection of virulence to $Y r 25, Y r 28, Y r 31, Y r 43, Y r 44, Y r T r 1$, and $Y r E x p 2$ in our study was not possible in the previous study, because they did not use wheat genotypes for these genes (Dawit et al. 2009). Virulences to these genes were very useful because they allowed us to compare the races identified in Ethiopia with those identified in the United States and other countries (Sharma-Poudyal et al. 2013; Wan and Chen 2014; Wan et al. 2016). All of these studies showed that these resistance genes are largely ineffective against the pathogen populations in the world but useful for differentiating different races.

Significant changes in frequency were detected for several virulences when comparing the present study with that of Dawit et al. (2009). Virulence to $\operatorname{Yr} 10$ increased from 16 to 35\%, $Y r 27$ from 91 to $100 \%$, and Vilmorin 23 from 5 to $30 \%$. In contrast, the frequency of virulence to $\operatorname{Yr} 8$ decreased from 99 to $56 \%, \operatorname{Yr} 32$ from 73 to $31 \%$, and $\mathrm{YrA}$ (which was recently defined as complementary genes $\mathrm{Yr} 73$ and $Y r 74$ ) (Dracatos et al. 2016) from 99 to 83\%. We could not determine whether the frequency difference-68\% in the study of Dawit et al. (2009) versus $100 \%$ in the present study-for virulence to $Y r 2$ was significant or not because different wheat cultivars were used. Heines VII, used in the study of Dawit et al. (2009), has two genes $(Y r 2$ and $Y r 25)$ whereas Kalyansona, used in the present study, has only Yr2 (Singh and Johnson 1988). Similarly, Dawit et al. (2009) used Rendezvous to represent $\operatorname{Yr} 17$ and found the virulence frequency at only $14 \%$, whereas we found the $\mathrm{Yrl} 17$ virulence frequency at $89 \%$ using the $\mathrm{Yr} 17$ single-gene line in the Avocet S background. Different temperatures used in the two studies could contribute to the frequency difference for $Y r 17$, because Dawit et al. (2009) used a relatively constant temperature $\left(16\right.$ to $\left.18^{\circ} \mathrm{C}\right)$, whereas we used a diurnal temperature cycle ranging from 4 to $20^{\circ} \mathrm{C}$ standardized in our program (Chen et al. 2002, 2010; Line and Qayoum 1992; Wan and Chen 2014; Wan et al. 2016). This diurnal temperature cycle simulates the natural temperatures in the early growth stage of wheat in most wheat production regions and allows us to separate all-stage resistance, which is race-specific and less under the influence of temperatures, from high-temperature adult-plant (HTAP) resistance, which is usually nonrace specific and more affected by temperatures (Chen 2005, 2013; Line and Qayoum 1992). Milus et al. (2015) reported that wheat lines with $\mathrm{Yr} 17$ have resistance or reduced disease on adult plants, and that the resistance is sensitive to temperatures. We have also obtained similar results even with the $\operatorname{Yr} 17$ near-isogenic line (A. M. Wan and $X$. M. Chen, unpublished data). We are currently conducting experiments to test our hypothesis that $\mathrm{Yr} 17$ is linked with a gene for HTAP resistance that is also introgressed from Aegilops ventricosa into wheat. Nevertheless, the diurnal temperature cycles allowed us to clearly differentiate isolates virulent to $\operatorname{Yr} 17$ from those avirulent to the gene by reducing the effect of HTAP resistance.

The detections of the virulences and their frequencies are generally consistent with a recent study on $P$. striiformis f. sp. tritici collections from various countries (Sharma-Poudyal et al. 2013). When compared with Kenya, the high frequencies of virulence in Ethiopia were comparable for $Y r 1, Y r 2, Y r 6, Y r 7, Y r 9, Y r 17, Y r 31$, and $Y r E x p 2$, and low frequencies of virulence for $\mathrm{Yr} 10$. However, significant differences were identified for $Y r 8, Y r 25, Y r 27, Y r 28$, and $Y r T y e$. The differences could be due to difference in year of collection, cultivars, and geographic regions with different cropping systems and climates in the two neighboring countries. The relatively small number of isolates from Kenya in the previous study and large number of isolates from Ethiopia in the present study might also contribute to the differences. Nevertheless, the highly frequent virulences detected in the present study were also detected at high frequencies across various countries, including Australia, Canada, Chile, China, Hungary, Kenya, Nepal, Pakistan, Turkey, and Uzbekistan in the previous study (Sharma-Poudyal et al. 2013), and also agree with the reports in the Global Rust Reference Center at Aarhus University (http://wheatrust.org). The results indicate that similar races have been predominant in different countries, consistent with the previous report of quick and wide spread of two strains of P. striiformis f. sp. tritici throughout the world (Hovmøller et al. 2008). In the present study, we identified 18 races using the recently established system for naming $P$. striiformis $\mathrm{f}$. sp. tritici races based on virulence/avirulence patterns on the $18 \mathrm{Yr}$ single-gene differentials (Wan and Chen 2014; Wan et al. 2016). This system allowed us to compare the races identified in Ethiopia with those identified in other countries. Among the 18 races identified in the present study, 4 races (PSTv-41, PSTv-47, PSTv-72, and PSTv-76) were identified first in the United States from 2011 to 2013 (Wan and Chen 2014; Wan et al. 2016; A. M. Wan and X. M. Chen, unpublished data) and the remaining 14 races were detected for the first time. The possibility of the four races being due to contamination can be ruled out because these races had very low frequencies (0 to $1.2 \%$ ) among the U.S. isolates we worked with in 2013 and 2014, and some of the Ethiopian isolates identified as these races had virulence/avirulence patterns on the seven supplementary differentials different from the U.S. isolates identified as the same races. The results indicate that, although races in Ethiopia are largely different from those in other countries, similar races can occur in different countries, even between Ethiopia and the United States on different continents. All of these races are virulent to $\operatorname{Yr} 8$ and $Y r 9$, which is the virulence phenotype of the aggressive strains widespread in the world (Hovmøller et al. 2008; Milus et al. 2009). Further studies are needed to characterize the Ethiopian isolates with molecular markers to compare with the populations in other countries.

Testing isolates from different sampling regions revealed notable regional differences in terms of race composition and virulence diversity. Arsi Robe had the highest number of races and value of virulence diversity, Holeta had the lowest number of races and value of virulence diversity, and Bale and Bekoji had intermediate numbers of races and values of diversity. These appear to be related to the differences in cropping systems and numbers of cultivars grown in these regions. In Arsi Robe, wheat is grown twice a year and a large number of both indigenous landraces and improved bread wheat cultivars are grown. The diverse host crops and cultivars should have allowed diverse races of $P$. striiformis $\mathrm{f}$. sp. tritici to infect and reproduce under the weather conditions favorable to stripe rust. The cropping systems in Bale (the Sinana area) and Bekoji (in the Arsi zone) are dominated by large-scale monocropping of modern bread wheat cultivars with a narrow genetic basis. The lack of adequate genetic variation in the background of modern wheat cultivars (Badebo 2002) may have selected some races and shaped the pathogen population to be at a low diversity.

Identification of races from the samples collected from bread wheat, durum wheat, and triticale did not show any separation of races by the different crops. The isolates from durum wheat were identified as six races (PSTv-41, PSTv-72, PSTv-105, PSTv-106, PSTV-113, and PSTv-139), which were all identified from isolates of bread wheat, except race PSTV-139, that was detected from only one durum wheat sample. Similarly, the only isolate from triticale collected from South Wollo (northern Ethiopia) was identified as PSTV-107, which was one of the most predominant races. Since 2006, a unique "triticale-aggressive" race has spread and caused severe damage on triticale throughout Europe (Hovmøller et al. 2016). This race is virulent on $Y r 2, Y r 6, Y r 7, Y r 8$, and $Y r 10$ but not on $Y r 1$, $Y r 3, Y r 4, Y r 9, Y r 17, Y r 25, Y r 32$, and $Y r S P$. The triticale isolate in the present study has a different virulence spectrum because it is virulent on $Y r 1, Y r 2, Y r 3, Y r 6, Y r 7, Y r 8, Y r 9, Y r 17$, and $Y r 25$ among the genes used in both studies. Studies with more samples from triticale are needed to determine whether the triticale-aggressive race is present in Ethiopia.

The evaluation of the 178 Ethiopian wheat accessions with two Ethiopian $P$. striiformis f. sp. tritici races identified in this study and three predominant races in the United States enabled us to characterize reactions of current Ethiopian bread wheat cultivars and landraces, and assess the impact of the most virulent race and predominant race on the cultivars and genetic stocks. In general, more entries were susceptible to the Ethiopian races than those susceptible to the predominant races of the United States. The different reactions of 
Ethiopian wheat germplasm to $P$. striiformis f. sp. tritici races in the two countries showed the importance of well-characterized local races for germplasm screening and resistance gene deployment. More importantly, we identified eight cultivars and five landraces that possess resistance or moderate resistance to all five tested races. Extensive data of screening the wheat entries in multienvironment field tests in Ethiopia and the United States confirmed the all-stage resistance in these selected entries and also indicated adult-plant resistance in some other entries (data not shown). These resistant entries should be useful for breeding for stripe-rust-resistant cultivars in both Ethiopia and the United States, and possibly in other countries. Further studies are needed to identify and map the resistance genes in these entries.

Because of limited information on stripe rust resistance genes in wheat cultivars in Ethiopia, it is difficult to connect races or virulence to particular resistance genes. Dawit et al. (2012) postulated different combinations of resistance genes $\operatorname{Yr} 2, \operatorname{Yr} 3 a, \operatorname{Yr} 4 a, \operatorname{Yr} 6, \operatorname{Yr} 7, \operatorname{Yr} 8, \operatorname{Yr} 9$, $Y r 27, Y r 32$, and $Y r S U$ in 24 Ethiopian bread wheat cultivars. Wheat cultivars with these genes could have selected the races with different combinations of the resistance genes. By testing six isolates representing different $P$. striiformis f. sp. tritici races in Ethiopia, they also found that genes $Y r 2, \operatorname{Yr} 6, Y r 7, Y r 8, Y r 9, Y r 27$, and $Y r 32$ are not effective against the $P$. striiformis $\mathrm{f}$. sp. tritici population, similar to the results of the present study. They reported that 'Wabe' and Tusie bread wheat were resistant to all $20 P$. striiformis f. sp. tritici races tested and mapped resistance genes in both Wabe and Tusie on chromosome 7BL and a gene in 'Suf-Omer' on 3BL. In our screening of wheat germplasm from Ethiopia, we have identified a large number of durum and bread wheat germplasm, mostly landraces, with excellent resistance to stripe rust (X. M. Chen, unpublished data). We have identified three new genes-Yr53, Yr64, and Yr65-that are effective against all $P$. striiformis f. sp. tritici races tested from durum wheat lines originating from Ethiopia and incorporated them into a bread wheat background (Cheng et al. 2014; Wang et al. 2012; Xu et al. 2013). These genes from Ethiopian landraces, the genes identified in commercial cultivars (Dawit et al. 2012), and genes identified from many other sources (Chen 2013; Rosewarne et al. 2013), including $Y r 5, Y r 15, Y r S P$, and $Y r T y e$, are effective against all races identified in these studies for developing wheat cultivars with resistance to stripe rust. Combining genes for effective all-stage resistance and those for HTAP resistance (Chen 2013) can be used to develop cultivars with high-level and durable resistance. Use of diverse resistance genes in wheat cultivars should reduce damage caused by currently existing and potentially new races. The races identified in the present study can be selected for use in screening wheat germplasm and breeding lines for effective stripe rust resistance. When identified, genes in the 13 resistant Ethiopian wheat entries obtained in the present study will contribute to the diversification of effective genes to be used in breeding programs.

\section{Acknowledgments}

This study was supported by the United States Department of AgricultureAgricultural Research Service (project number 5348-22000-015-00D) and Washington Grain Commission. We thank Monsanto Beachell-Borlaug International Scholars Program for the scholarship to K. Muleta.

\section{Literature Cited}

Abeyo, B., Hodson, D., Hundie, B., Woldeab, G., Girma, B., Badebo, A., Alemayehu, Y., Jobe, T., Tegegn, A., and Denbel, W. 2014. Cultivating success in Ethiopia: The contrasting stripe rust situations in 2010 and 2013. Poster 65, BGRI 2014 Technical Workshop, Obregon, Mexico.

Aklilu, M. 1995. Wheat rust races identified in virulence survey in Ethiopia. Pages 458-461 in: The Ninth Regional Wheat Workshop: For Eastern, Central and Southern Africa. D. G. Tanner, T. S., Payne, and O. S. Abdalla, eds. Addis Ababa, Ethiopia. Online publication. http://repository.cimmyt.org/xmlui/handle/ $10883 / 1231$

Atilaw, A., Bishaw, Z., Eticha, F., Gelalcha, S., Tadesse, Z., Aliye, S., Abdalla, O., Fikre, A., Ahmed, S., and Silim, S. 2014. Controlling wheat rusts and ensuring food security through deployment of resistant varieties in Ethiopia. Page 19 in: Proc. 2nd Int. Wheat Stripe Rust Symp. Izmir, Turkey.

Badebo, A. 2002. Breeding bread wheat with multiple disease resistance and high yield for the Ethiopian highlands: Broadening the genetic basis of yellow rust and tan spot resistance. Ph.D. thesis, Georg-August University, Goettingen, Germany.
Badebo, A., Bekele, E., Bekele, B., Hundie, B., Degefa, M., Tekalign, A., Ayalew, M., Ayalew, A., Meles, K., and Abebe, F. 2008. Review of two decades of research on diseases of small cereal crops. Pages 375-429 in: Increasing Crop Production through Improved Plant Protection, Vol. 1, Proc. 14th Annu. Conf. Plant Prot. Soc. Ethiopia (PPSE). A. Taddese ed. Addis Ababa, Ethiopia.

Bekele, H., Shambel, K., and Dereje, H. 2002. Seasonal variations in the occurrence of wheat stripe rust in Bale highlands. Pest Manage. J. Ethiopia 6:65-72.

Chen, W. Q., Wellings, C., Chen, X. M., Kang, Z. S., and Liu, T. G. 2014. Wheat stripe (yellow) rust caused by Puccinia striiformis f. sp. tritici. Mol. Plant Pathol. 15:433-446.

Chen, X. M. 2005. Epidemiology and control of stripe rust [Puccinia striiformis $\mathrm{f}$. sp. tritici] on wheat. Can. J. Plant Pathol. 27:314-337.

Chen, X. M. 2013. High-temperature adult-plant resistance, key for sustainable control of stripe rust. Am. J. Plant Sci. 4:608-627.

Chen, X. M., and Line, R. F. 1992. Inheritance of stripe rust resistance in wheat cultivars used to differentiate races of Puccinia striiformis in North America Phytopathology 82:633-637.

Chen, X. M., Moore, M. K., Milus, E. A., Long, D. L., Line, R. F., Marshall, D., and Jackson, L. 2002. Wheat stripe rust epidemics and races of Puccinia striiformis f. sp. tritici in the United States in 2000. Plant Dis. 86:39-46.

Chen, X. M., Penman, L., Wan, A. M., and Cheng, P. 2010. Virulence races of Puccinia striiformis f. sp. tritici in 2006 and 2007 and development of wheat stripe rust and distributions, dynamics, and evolutionary relationships of races from 2000 to 2007 in the United States. Can. J. Plant Pathol. 32:315-333.

Cheng, P., Xu, L. S., Wang, M. N., See, D. R., and Chen, X. M. 2014. Molecular mapping of genes Yr64 and Yr65 for stripe rust resistance in hexaploid derivatives of durum wheat accessions PI 331260 and PI 480016. Theor. Appl. Genet. 127:2267-2277.

CSA. 2014. Agricultural Sample Survey 2014/2015 (2006 E.C.). Vol. 1. Report on Area and Production of Major Crops (Private Peasant Holdings, Meher Season). Online publication. Central Statistics Agency (CSA), Addis Ababa, Ethiopia. www.csa.gov.et/

Dawit, W., Flath, K., Weber, W. E., Schumann, E., and Kosman, E. 2009 Virulence and diversity of Puccinia striiformis f. sp. tritici in Ethiopia. Can. J. Plant Pathol. 31:211-219.

Dawit, W., Flath, K., Weber, W. E., Schumann, E., Röder, M. S., and Chen, X. M. 2012. Postulation and mapping of seedling stripe rust resistance genes in Ethiopian bread wheat cultivars. J. Plant Pathol. 94:403-409.

Dereje, H., and Chemeda, F. 2006. Epidemics of stripe rust (Puccinia striiformis) on common wheat (Triticum aestivum) in the highlands of Bale, south eastern Ethiopia. Crop Prot. 26:1209-1218.

Dracatos, P. M., Zhang, P., Park, R. F., McIntosh, R. A., and Wellings, C. R. 2016 Complementary resistance genes in wheat selection 'Avocet $\mathrm{R}$ ' confer resistance to stripe rust. Theor. Appl. Genet. 129:65-76.

FAOSTAT. 2014. FAO Statistical Databases. Online publication. http://faostat fao.org/

Herrmann, A., Dinoor, A., Schachtel, G. A., and Kosman, E. 2009. Virulence Analysis Tool (VAT), User Manual. Online publication. http://www1.uni-giessen. de/va-tipp/VatMANUAL.pdf

Hovmøller, M. S., Walter, S., Bayles, R. A., Hubbard, A., Flath, K., Sommerfeldt, N., Leconte, M., Czembor, P., Rodriguez-Algaba, J., Thach, T., Hansen, J. G., Lassen, P., Justesen, A. F., Ali, S., and de Vallavieille-Pope, C. 2016. Replacement of the European wheat yellow rust population by new races from the centre of diversity in the near-Himalayan region. Plant Pathol. 65:402-411.

Hovmøller, M. S., Yahyaoui, A. H., Miles, E. A., and Justesen, A. F. 2008. Rapid global spread of two aggressive strains of a wheat rust fungus. Mol. Ecol. 17: 3818-3826.

Johnson, R., Stubbs, R. W., Fuchs, E., and Chamberlain, N. H. 1972. Nomenclature for physiologic races of Puccinia striiformis infecting wheat. Trans. Br. Mycol. Soc. 58:475-480.

Kosman, E. 1996. Difference and diversity of plant pathogen populations: A new approach for measuring. Phytopathology 86:1152-1155.

Li, G. Q., Li, Z. F., Yang, W. Y., Zhang, Y., He, Z. H., Xu, S. C., Singh, R. P., Qu, Y. Y., and Xia, X. C. 2006. Molecular mapping of stripe rust resistance gene YrCH42 in Chinese wheat cultivar Chuanmai 42 and its allelism with $Y r 24$ and Yr26. Theor. Appl. Genet. 112:1434-1440.

Line, R. F., and Qayoum, A. 1992. Virulence, aggressiveness, evolution, and distribution of races of Puccinia striiformis (the cause of stripe rust of wheat) in North America, 1968-87. U. S. Dep. Agric. Agric. Res. Serv. Tech. Bull. 1788

McIntosh, R. A., Yamazaki, Y., Dubcovsky, J., Rogers, J., Morris, C., Appels, R., and Xia, X. C. 2013. Catalogue of gene symbols for wheat. In: 12th Int. Wheat Genet. Symp. Yokohama, Japan. Online publication. http://shigen.nig.ac.jp/ wheat/komugi/genes/download.jsp

McVey, D. V., Nazim, M., Leonard, K. J., and Long, D. L. 2004. Patterns of virulence diversity in Puccinia triticina on wheat in Egypt and the United States in 1998-2000. Plant Dis. 88:271-279.

Mengistu, H., Getaneh, W., Yeshi, A., Rebka, D., and Ayele, B. 1991. Wheat pathology research in Ethiopia. Pages 173-217 in: Wheat Research in Ethiopia: A Historical Perspective. G. Hailu, D. G. Tanner, and H. Mengistu, eds. IAR/CIMMYT, Addis Ababa, Ethiopia.

Milus, E. A., Kristensen, K., and Hovmøller, M. S. 2009. Evidence for increasingly aggressiveness in a recent widespread strain of Puccinia striiformis f. sp. tritic causing stripe rust of wheat. Phytopathology 99:89-94. 
Milus, E. A., Lee, K. D., and Brown-Guedira, G. 2015. Characterization of stripe rust resistance in wheat lines with resistance gene $\mathrm{Yrll}$ and implications for evaluating resistance and virulence. Phytopathology 105:1123-1130.

Mulugeta, N. 1986. Estimates of phenotypic diversity and breeding potential of Ethiopian wheat. Hereditas 104:41-48.

Negassa, A., Shiferaw, B., Koo, J., Sonder, K., Smale, M., Braun, H. J., Gbegbelegbe, S., Guo, Z., Hodson, D., Wood, S., Payne, T., and Abeyo, B. 2013. The Potential for Wheat Production in Africa: Analysis of Biophysical Suitability and Economic Profitability. CIMMYT, Mexico, D.F. Mexico.

Nei, M. 1973. Analysis of gene diversity in subdivided populations. Proc. Natl. Acad. Sci. USA 70:3321-3323.

Rosewarne, G. M., Herrera-Foessel, S. A., Singh, R. P., Huerta-Espino, J., Lan, C. X., and He, Z. H. 2013. Quantitative trait loci of stripe rust resistance in wheat. Theor. Appl. Genet. 126:2427-2449.

Sharma-Poudyal, D., Chen, X. M., Wan, A. M., Zhan, G. M., Kang, Z. S., Cao, S. Q., Jin, S. L., Morgounov, A., Akin, B., Mert, Z., Shah, S. J. A., Bux, H., Ashraf, M., Sharma, R. C., Madariaga, R., Puri, K. D., Wellings, C., Xi, K. Q., Wanyera, R., Manninger, K., Ganzález, M. I., Koyda, M., Sanin, S., and Patzek, L. J. 2013. Virulence characterization of international collections of the wheat stripe rust pathogen, Puccinia striiformis f. sp. tritici. Plant Dis. 97:379-386.

Singh, H., and Johnson, R. 1988. Genetics of resistance to yellow rust in Heines VII, Soissonais and Kalyansona. Pages 885-890 in: Proc. 7th Int. Wheat Genet. Symp., T. E. Miller and R. M. D. Koebner eds. Cambridge, UK.
Wan, A. M., and Chen, X. M. 2014. Virulence characterization of Puccinia striiformis f. sp. tritici using a new set of $Y r$ single-gene line differentials in the United States in 2010. Plant Dis. 98:1534-1542.

Wan, A. M., Chen, X. M., and Yuen, J. 2016. Races of Puccinia striiformis f. sp. tritici in the United States in 2011 and 2012 and comparison with races in 2010. Plant Dis. 100:966-975.

Wang, M. N., Chen, X. M., Xu, L. S., Cheng, P., and Bockelman, H. E. 2012 Registration of 70 common spring wheat germplasm lines resistant to stripe rust. J. Plant Regist. 6:104-110.

Wellings, C. R. 2011. Global status of stripe rust: A review of historical and current threats. Euphytica 179:129-141.

Wubishet, A. T., Chemeda, F. G., and Bekele, H. E. 2015. Effects of environment on epidemics of yellow rust (Puccinia striiformis West.) of bread wheat (Triticum aestivum L.) in Bale highlands, South-eastern Ethiopia, 2015. Global J. Pests Dis. Crop Prot. 3:96-107.

Xu, L. S., Wang, M. N., Cheng, P., Kang, Z. S., Hulbert, S. H., and Chen, X. M. 2013. Molecular mapping of Yr53, a new gene for stripe rust resistance in durum wheat accession PI 480148 and its transfer to common wheat. Theor. Appl. Genet. 126:523-533.

Zewde, L., Tanner, D. G., Elias, E., Gorfu, A., Tarekegne, A., Geleto, T., Yilma, Z., and Gebre, H. 1989. The relative importance of yield limiting factors on bread wheat in the Ethiopian highlands. Pages 214-223 in: Sixth Regional Wheat Workshop: For Eastern, Central and Southern Africa, Addis Ababa, Ethiopia. D. G. Tanner, D. G., Van Ginkel, and W. Mwangi eds. CIMMYT Mexico, D.F. Mexico. 